\title{
COMPOSITION AS A FUNDAMENTAL DISCIPLINE IN THE PROCESS OF PAINTERS TEACHING
}

\author{
КОМПОЗИЦІЯ ЯК ПРОВІДНА ДИСЦИПЛІНА В ПРОЦЕСІ НАВЧАННЯ \\ ХУДОЖНИКІВ-ЖИВОПИСЦІВ
}

\author{
Opanas TYTENKO, \\ Associate Professor \\ Опанас ТИТЕНКО, \\ доцент \\ panas.tytenko@gmail.com \\ https://orcid.org/0000-0001-9306-7877 \\ Kyiv State Academy of Decorative \\ and Applied Art and Design by \\ M. Boychuk \\ 32, M. Boychuk St., \\ Kyiv, 01103 \\ Original manuscript received: October 07, 2021 \\ Revised manuscript accepted: December 15, 2021
}

\begin{abstract}
The author in the article considers some aspects of creating a composition in painting, explores the changes in the composition of the picture throughout the history of art. Proves that creativity and creativity are important factors for creating a composition, which can be defined as a person's ability to constructive, non-standard thinking. This topic is very relevant for future artists. The rules, constructions of the composition defined in this article will help to make work (a photo, a collage, drawing, a picture) harmonious and balanced. The author emphasizes that it is not enough to have natural talent and taste to harmoniously combine objects in the chosen format. You need to know certain rules to succeed. For example, the rule of the golden ratio. The author draws attention to the fact that the composition is built according to certain laws. Its rules and techniques are interconnected and apply at all times of work on the composition. Everything is aimed at achieving the expressiveness and integrity of the work of art. To create an emotional and figurative composition, the artist must learn to use interesting events, characters, motives, angles and states. Emphasizes that the constant execution of sketches, sketches and sketches from nature develops not only the eye and hand, but also compositional thinking. The author reminds that the means of composition can be a variety of techniques and rules. And also that the search for an original compositional solution, the use of means of artistic expression, the most suitable for the implementation of the artist's idea, are the basis of the expressiveness of the composition. It is important that the subject "Composition» is closely related to the content of subjects "Drawing», "Painting», "Easel Composition», which set general goals and objectives according to the basic laws of compositional construction, graphic and pictorial performance. An important role in this process is given to mastering the knowledge of theory in the field of art history. The subject "Composition» is aimed at acquiring deep knowledge, skills and abilities in the learning process, obtaining art education, as well as the aesthetic education of students.
\end{abstract}

Key words: composition, art, artists, artists, canon, age, creativity, means, color, contrast. 
Вступ. Існує думка, що композиція в станковому живописі має сталі позиції, які не змінюються століттями. Але, якщо уважно роздивитися твори різних віків, стає зрозумілим, що кожна доба надавала перевагу тій чи іншій системі композиції. Але, без сумніву, у композиції $є$ свої закони, що складаються в процесі художньої практики і розвитку теорії. Звичайно, ніякими правилами не можна замінити відсутність художніх здібностей і творчої обдарованості. Талановиті художники та студенти можуть інтуїтивно знаходити правильні композиційні рішення, але для розвитку композиційного обдарування необхідно вивчати теорію і багато працювати над іiї практичною реалізацією.

Поняття «творчість» тісно переплітається 3 поняттям «креативність», але не тотожне йому. Якщо творчість розуміється як процес, що має певну специфіку і приводить до створення нового, то креативність розглядається як потенціал, внутрішній ресурс людини, його здатність відмовитися від стереотипних способів мислення або здатність виявляти нові варіанти вирішення проблем. Креативність також можна визначити як здатність людини до конструктивного, нестандартного мислення і поведінки, усвідомлення та розвитку свого досвіду. Саме творчість і креативність є фракторами, які сприяють створенню непересічних композицій в образотворчому мистецтві. Схем побудови композиції може бути безліч, але у творчій роботі важливо пам'ятати, що вибирати схему необхідно в залежності від того, якого художньо-образного вирішення хоче досягти художник. Не слід думати, що предмети натюрморту або складові жанрової картини треба обов'язково розташовувати за схемою.

Методи та методики дослідження. Композиція будується за певними законами. Її правила і прийоми взаємопов'язані між собою i діють в усі моменти роботи над композицією. Усе спрямовано на досягнення виразності й цілісності художнього твору. Художнику для створення емоційної та образної композиції необхідно вчитися бачити в нашому житті цікаві події, персонажі, мотиви, ракурси і стани. Постійне виконання начерків, замальовок і етюдів з натури розвиває не лише око і руку, але й композиційне мислення.

Варто нагадати, що засоби композиції включають: формат, простір, композиційний центр, рівновагу, ритм, контраст, світлотінь, колір, декоративність, динаміку і статику, симетрію й асиметрію, відкритість і замкнутість, цілісність. Таким чином, засоби композиції - це все, що необхідно для її створення, в тому числі її прийоми і правила. Вони різноманітні, інакше їх можна назвати засобами художньої виразності композиції. Пошук оригінального композиційного рішення, використання засобів художньої виразності, найбільш придатних для втілення задуму художника, складають основи виразності композиції. Вибір найбільш виразного сюжету для композиції - теж непросте завдання. Один і той же сюжет люди сприймають і тлумачать порізному, тобто створюють свою версію змісту. 
У широкому сенсі слово «композиція» вживають не лише художники, а й музиканти, режисери кіно та театру, дизайнери інтер'єру та ландшафту, фрлористи та ін. Якщо заглянути в словник, то комозиція (лат. compositio - складання, зв'язування, складання, з'єднання) складання цілого з частин. Без сумніву, у контексті нашої статті, нас цікавить саме композиція в образотворчому мистецтві. На відміну від рисунка, кольору, лінії, обсягу, простору, в образотворчому мистецтві композиція $є$ не одним з компонентів художньої форми, а художньообразну, змістовно-формальну цілісність - найбільш складний і досконалий тип структури, в якому всі елементи органічно пов'язані між собою. Основний задум композиції може бути побудований на контрастах. Контраст як універсальний засіб допомагає створити яскравий і виразний твір. Леонардо да Вінчі в «Трактаті про живопис» говорив про необхідність використовувати контрасти величин (високого й низького, великого й маленького, товстого й тонкого), фактур, матеріалів, обсягу, площин тощо. Досвідчені художники знають, що задля досягнення цілісності композиції слід виділити центр уваги, де буде розташовано головне, відмовитися від другорядних деталей, приглушити ті контрасти, що відволікають від головного. Композиційної цілісності можна домогтися, якщо об'єднати світлом, тоном або колоритом усі частини твору.

Цілісність композиції залежить від здатності художника підпорядкувати другорядне головному, від поєднання всіх елементів між собою. Тобто не можна допустити, щоб погляд в першу чергу зупинявся на чомусь другорядному в композиції, у той час як найважливіше залишалося непоміченим. Кожна деталь повинна сприйматися як необхідна, що додає щось нове до розвитку задуму автора. Легенди різних народів свідчать, що найбільш талановиті художники й архітектори отримували від богів книги, що містять священне знання. Не рідко жерці були художниками, а також хранителями знань, передаючи їх з покоління в покоління. Самі традиції сприймалися не як звід необхідних правил, а щось священне, передане людям, божественне одкровення. Ще у V-III тисячоліттях уже виникають особливості композиції, хоча різновидів її було ще не так багато. I тут, можливо, найкраще підійшло б слово «канон». Канон (грец. Kavúv) незмінна (консервативна) традиційна, що не підлягає перегляду, сукупність законів, норм і правил у різних сферах діяльності і життя людини. У коло понять, регламентованих каноном, входили: сюжети, пози, жести, розміри фігур і предметів. Крім цього, правила канону поширювалися також на вибір матеріалу і кольору в різних видах мистецтва. Регламентувався також порядок проведення робіт.

Для сучасної людини те, що створювали єгипетські боги, є дуже незвичним. Фігуру зображували одночасно і спереду, і збоку. Художник намагався показати людське тіло найбільш всебічно, але не вмів перевести тривимірну форму на площину, бо не знав про скорочення площин. Тому рисував плечі і очі - в фас, тіло і обличчя - у профіль. За версією професора Ф.Шварца, людина представлена тут в реальності в 
4-х вимірах. Поступово сформувалися локальні художні школи, де навчалися й творили яскраві творчі індивідуальності. Єгипетськими художниками були втілені в струнку систему основні засоби пластичних мистецтв: обсяг, маса, площина, лінія, силует, кольорова пляма; склалася канонізована форма зображення людської фрігури на площині.

Характерною рисою єгипетського образотворчого мистецтва, без сумніву, є ставлення до відображення життя та смерті, часу і простору. Мистецтво вважалося носієм життя вічного, і тому позбавлялося всього випадкового, швидкоплинного, ілюзорного. Канон залишався незмінним протягом багатьох тисяч років. Усередині контуру підготовчого рисунка майстер міг моделювати зображення. Однак на всіх етапах роботи він був пов'язаний цілою системою правил. Кожна фігура поєднує фррагменти зображень, даних в різному ракурсі, з різних точок зору: торс зображується в фрас або в три чверті, голова і ноги - в профіль. У часи Нового царства композиція розписів і рельєфрів стає значно різноманітнішими: сцени полювання, підношення дарів не підлягали суворому канону, більш вільними стали розписи, присвячені війні. Але ще досить довго фрараони та їхні наближені були значно більшими за всіх, хто зображувався в сюжеті. Схожа ситуація відбувалася з композицією рельєфів і розписів у країнах Дворіччя. Але все ж тут можна знайти більше різноманітності. Цікавим прикладом була стела Лагашського правителя Еанаатума. Його зображено на чолі війська на верхній частині так званої «Стели коршаків» (середина XXIII ст до н.е. (Лувр, Париж). Ще не володіючи вповні навичками перспективи, митець, який створив стелу, зміг подолати двовимірність і на невеликій площині зобразити величезне могутнє військо, озброєне списами.

У XVII столітті великий іспанський художник Дієго Веласкес практично повторив цей прийом у відомому творі «Здача Бреди», який має другу неофіційну назву «Списи». За воїнами, які стоять на першому плані, ми бачимо лише вершечки шоломів, списи і прапори, що майорять до самого горизонту. Таким чином художник досягає масовості у своєму творі. I досить проста й симетрична композиція стає більш розвинутою вглиб полотна. Подібну композицію ми можемо зустріти і у Джотто, в його релігійних сюжетах, де святі, які стоять один за одним, зображені завдяки німбам, що виглядають, наче нависаючи над попереднім рядом святих. Немає навіть невеличких щілин, де можна було б розгледіти обличчя або плече - лише німби. Але глядач вірить, що за одним рядом є другий, за другим - третій. Усе вище згадане дає можливість зрозуміти, що протягом століть та навіть тисячоліть деякі композиційні прийоми залишаються незмінними. При тому, що митці ніколи не бачили творів один одного.

Античний світ також вніс свої корективи в створення сталих композицій. Тут теж існували певні канони, адже вони задають сукупність художніх прийомів чи правил, обов'язкових для тієї чи іншої доби. У мистецтві античної Греції найпростіше роздивитися зміни, що відбулися в композиції - у вазописі. Саме тут ми бачимо їх, вписані в коло, фризові, вписані в трикутник, вільні, як в стилі «Камарес» тощо. 
На Криті в Кносському палаці було знайдено розписи, що дають уяву про те, як давні греки «вписували» живописні композиції в архітектуру. Глядач може побачити однофігурну, двофрігурну композиції. Цікавий приклад - Цар-жрець. (Принц з ліліями), (Археологічний музей Іракліон. Фреска з палацу в Кноссі. XIV ст. до н.е.). Фігура царя нагадує розпису Древнього Єгипту - ноги, голова в профіль, тіло, розвернуте до глядача. Фігура чітко вписана в прямокутник, квіти ззаду на світлому тлі і спереду на основному врівноважують постать.

В античному Римі композиція отримує нові можливості, про що свідчать розписи, відкриті в Колізеї, Помпеї і Геркуланума, а також інших місцях, де були проведені археологічні роботи. Це численні сцени гладіаторських боїв, бенкетів тощо. Композиції розписів і мозаїк інколи нагадували розписи на грецькій кераміці. Давні художники інтуїтивно використовували бачене ними раніше. Творчі люди Античності і доби Відродження намагалися знайти ідеальні пропорції людського тіла і вивести незмінні, математично обґрунтовані правила побудови не лише самої фігури людини, а й антропоморфної композиції. Профресор А. Лосєв у своїй роботі «Історія античної естетики» визначає канон як кількісноструктурну модель художнього твору такого стилю, який, будучи виразником певних соціально-історичних показників, інтерпретується як принцип створення відомого безлічі творів. Надалі у часи Візантії процвітає канон не менш суворий, а скоріше більш, ніж в Єгипті чи античному світі. Це пов'язано з релігійними законами. Існували суворі закони щодо зображення святих. Безумовно, розвиток композиції розпочався за доби Відродження. Художники працювали вільно, хоча деякі замовники висували свої вимоги. Крім того, Леонардо створив камеру-обскура. I нею захопилися видатні митці. Ян Вермер міняв композицію своїх картин до трьох разів, що доведено рентгенівським дослідженням.

Ясно, що свої зміни сталися за доби бароко. Караваджо у своїх картинах так змінює композицію, що його герої буквально «вивалюються» на глядача. Він добивається експресії введенням контрастного освітлення. I робить те, що до нього ніхто не робив: вводить так звану «жаб'ячу точку зору», 3 якої глядач повинен розглядати роботу. У рококо популярними стають «фривольні сцени»: полювання чоловіків і жінок, сцени пікніків. Композиція в них складна і часто заплутана. На початку XX століття в образотворчому мистецтві відбувається рішучий розрив норм, закорінених протягом декількох століть. Імпресіоністи назавжди розривають традиції старої композиційної системи. Безумовно, подальший етап розвитку станкової композиції заслуговує окремого ґрунтовного дослідження, яке зможе розкрити й окреслити всі можливі шляхи розвою композиційних вирішень.

Висновки. Часом свідоме порушення композиційних правил стає творчим успіхом, допомагає художникові точніше втілити свій задум, тобто бувають винятки з правил. Варто згадати твори таких геніїв світового 
мистецтва, як Пікассо, Врубель, Піссаро, Гоген, Ван Гог та ін. Композиції творів наведених митців не вкладаються в Прокрустове ложе академічної композиції: фрагментарність, зумисне спотворення перспективи, гротескність, зміщення зорового центру - все це стає у пригоді творчому процесу, і на світ з'являються шедеври.

\section{Література} 1986. $326 \mathrm{c}$.

Аксенов Ю. Г., Левидова М. М. Цвет и линия. Москва : Сов. художник, 1968. $184 \mathrm{c}$.

Алексеев В. В. Изобразительное искусство и школа. Москва : Педагогика,

Васильєва О., Поклад І. Розвиток творчої особистості дитини в образотворчій діяльності. Мистецтво та освіта. 2002. № 2. С. $42-43$.

Верб В. А. Искусство и художественное развитие учащихся. Ленинград : Наука, 1977. 116 с.

Волинка Г. І., Гусєв В. І., Мозгова Н. Г., О Огородник І. В., Федів Ю. О. Історія філософії в ії̈ зв'язку з освітою. Київ : Каравела, 2006. ISBN 966-8019-46.

Виноградова Г. Малювання з натури. Київ : Рад. школа, 1976. 118 с. $224 \mathrm{c}$.

Гандзій П. А., Левицький Ф. Д. Уроки малювання. Київ : Рад. школа, 1975.

\section{References:}

Aksenov, Yu. G., Levidova, M. M. (1986). Tsvet $i$ liniya [Color and Line]. Moskva : Sov. Hudozhnik [in Russian].

Alekseev, V. V. (1968). Izobrazitelnoe iskusstvo i shkola [Fine arts and school]. Moskva : Pedagogika [in Russian].

Vasylieva, O., Poklad, I. (2002). Rozvytok tvorchoi osobystosti dytyny $v$ obrazotvorchii diialnosti [The development of the creative specialty of the child in the figurative activity]. Mystetstvo ta osvita - Art and education, 2, 42-43 [in Ukrainian].

Verb, V. A. (1977). Iskusstvo i hudozhestvennoe razvitie uchaschihsya [Art and artistic development of students]. Leningrad : Nauka [in Russian].

Volynka, H. I., Husiev, V. I., Mozghova, N. H., Ohorodnyk, I. V., Fediv, Yu. O. (2006). Istoriia filosofii v yii zviazku z osvitoiu [History of philosophy in its connection with education]. Kyiv : Karavela. ISBN 966-8019-46 [in Ukrainian].

Vynohradova, H. (1976). Maliuvannia z natury [Drawing from nature]. Kyiv : Rad. shkola [in Ukrainian].

Handzii, P. A., Levytskyi, F. D. (1975). Uroky maliuvannia [Drawing lessons]. Kyiv : Rad. shkola [in Ukrainian].

\section{АНОТАЦІЯ}

Автор у статті розелядає деякі аспекти створення композиції в живописі, досліджує зміни в композиції картини протягом усіеї історії мистецтва. Доводить, що креативність і творчість є важливими фракторами для створенні композиції, які можна визначити як здатність людини до конструктивного, нестандартного мислення. Ця тема дуже актуальна для майбутніх художників образотворчого мистецтва. Правила побудови композиції, визначені в чій статті, допоможуть зробити роботу (фотограсрію, колаж, рисунок, картину) гармонійною й збалансованою. Автор наголошує на тому, що недостатньо мати природний талант і смак, щоб гармонійно поєднувати об'єкти в обраному форматі. Потрібно знати певні правила, щоб домогтися успіху. Наприклад, правило золотого перетину. Автор звертає увагу на те, що композиція будується за певними законами. Iї правила і прийоми взаємопов'язані між собою $i$ 
діють в усі моменти роботи над композицією. Усе спрямовано на досягнення виразності й иілісності художнього твору. Художнику для створення емоційної й образної композиції необхідно вчитися використовувати цікаві події, персонажі, мотиви, ракурси і стани. Наголошує на тому, що постійне виконання начерків, замальовок $i$ етюдів з натури розвиває не лише око і руку, а й композиційне мислення. Автор нагадує, що засобами композиції можуть бути різноманітні прийоми і правила. А також, що пошук оригінального композиційного рішення, використання засобів художньої виразності, найбільш придатних для втілення задуму художника, складають основи виразності композиції. Важливим є те, що навчальний предмет «Композиція» тісно пов'язаний зі змістом навчальних предметів "Рисунок», "Живопис», «Композиція станкова», в яких закладені загальні цілі $i$ завдання за основними законами композиційної побудови, графрічного і живописного виконання. Важлива роль у цьому процесі відведена оволодінню знаннями теорії в галузі історії мистецтв. Навчальний предмет «Композиція» спрямований на засвоєння глибоких знань, умінь і навичок в процесі навчання, отримання художньої освіти, а також на естетичне виховання студентів.

Ключові слова: композиція, мистецтво, художники, митиі, канон, віки, креативність, засоби, колір, контраст. 